\title{
AMELIORATING THE ANTI-NUTRITIONAL FACTORS EFFECT IN ATRIPLEX HALIMUS ON SHEEP AND GOATS BY ENSILING OR POLYETHELENE GLYCOL SUPPLEMENTATION
}

\author{
H.H. Abd El-Rahman, M. I. Mohamed, A.E.A. Gehad and I.M. \\ Awadallah
}

Department of Animal Productin, National Research Center, Dokki,P.O. 12311, Giza, Egypt

\section{SUMMARY}

Succulent twigs of Atriplex halimus naturally grown in Nubaria desert area were cut and sun dried (AH), or ensiled (AS). The AH was offered either alone or with daily supplementation of polyethelene glycol $(20 \mathrm{~g} P E G / \mathrm{kg}$ DMI) as a tannin complex agent to sheep and goats. Berseem (Trifolium alexandrinum) hay (BH) was used as a control. Animals were offered crushed barley grains to cover $50 \%$ of maintenance requirements, while tested forages were offered ad lib.

The nutrients proximate analysis of $B H$ was comparable to that of $A$. halimus. The average daily DM intake by both sheep and goats from $B H\left(32.0 \mathrm{~g} / \mathrm{kg} \mathrm{w}^{0.75}\right)$ was higher $(P<0.01)$ than AH, AS and AH+PEG, which ranged between 20.40 and 22.74 $\mathrm{g} / \mathrm{kg} \mathrm{w}^{0.75}$, due to A. halimus high content of total tannin $(95.6 \mathrm{~g} / \mathrm{kg} \mathrm{DM})$ and its high contents of ash and $\mathrm{NaCl}$. Nutrients digestibility coefficients of $\mathrm{BH}$ ration were better $(P<0.01)$ than those of $A H$ and $A H+P E G$ rations, meanwhile they were comparable to those AS one. Ensiled A. halimus showed better digestibilities than AH alone $(P<0.01)$ or with $P E G$ supplementation, but the differences were only significant $(P<0.01)$ with $C F$ and NFE. Crude protein digestibility of $A H$ was raised $(P<0.01)$ from $49.3 \%$ without PEG to $54.19 \%$ with PEG. Moreover, $N$ balance $(P<0.01)$ and its percent of $N$ intake were also high. Supplementing animals fed A. halimus by PEG improved $(P<0.01) \mathrm{N}$ balance and its percent to $N$ intake, being $9.68 \%$ vs $8.03 \%$.

It was concluded that ensiling $A$. halimus showed better nutritional results by sheep and goats than PEG supplementation. Moreover, it is easier to be practiced and coul lower feeding costs.

Keywords: Sheep, goat, atriplex halimus, anti-nutritional factors, ensiling, polyethelene glycol

\section{INTRODUCTION}

Browse plants play a significant role in nutrition of ruminant livestock in tropical and sub-tropical regions. Browse species, because of their resistance to heat, drought, salinity, alkalinity, drifting sand, grazing and repeated cutting, are the major feed resources during the dry season ( Fagg and Stewart, 1994) . In addition, a major advantage of browses over herbaceous legumes and grasses is their higher crude protein content. However, due to the presence of secondary plant metabolites 
(particularly tannins) in browses, digestibility of protein and organic matter in these feeds is low (Terrill et al., 1992; Silanikove et al., 1997; Waghorn and Shelton, 1997). This limits the availability of nutrients for ruminant livestock. Tannins have both beneficial and adverse effects. Beneficial effects of tannins include suppression of bloat (Jones et al., 1973) and protection of dietary proteins in the rumen (Waghorn et al., 1994). The adverse effects of tannins are associated with their ability to bind with dietary proteins, carbohydrates and minerals (McSweeney et al., 2001).

Crude protein in the browses range from 54.0 to $300.0 \mathrm{~g} / \mathrm{kg}$. However, the browses contained considerable amounts of secondary plant metabolites, particularly tannins which ranged from 7.0 to $214 \mathrm{~g} / \mathrm{kg}$ dry matter as tannic acid equivalent (Getachew et al., 2002).

Saltbushes (Atriplex spp.) represents an important group of browses. They produce considerable amounts of biomass that can be utilized when herbaceous forage is scare. Atriplex halimus is found in semi-arid environments in the Mediterranean basin, where Egypt is located, and is valued as livestock forage when herbage availability is low (Le Houerou, 1993).

Atriplex halimus is characterized by its high ash and crude fiber, moderate crude protein and low crude fat contents (Gihad, 1993). However, it contains up to $10 \%$ sodium chloride and secondary plant metabolites, one of them is tannin, which considerably affects its palatability and nutritive value.

The objectives of this work were to study the effect either ensiling A. halimus or supplementing animals by polyethelene glycol (PEG) as a tannin complexing agent on its palatability and digestion by sheep and goats.

\section{MATERIALS AND METHODS}

This study was conducted at Nubaria Experimental Farm, El- Bostan, Behaira Governorate and laboratories of Animal Department, NRC, Giza, Egypt. Succulent twigs of Atriplex halimus shrubs naturally grown in Nubaria desert area were cut and either sun dried or ensiled. Dried and ensiled materials were defined as hay (AH) and silage (AS). The AH was fed either alone or with a daily oral supplement of polyethelene glycol (AH+PEG) at the level of $20 \mathrm{~g} / \mathrm{kg}$ DM intake. Hay was made by chopping and spreading the cut twigs on a thin plastic sheet to avoid mechanical losses and sand contamination.

Silage was made by chopping the cut twigs and adding $10 \%$ of its weight sugar cane molasses which was deluted by fresh water. The mixture was ensiled for 45 days in hard plastic barrels with tight sealed cover.

Three mature male sheep (31 kg) and goats $(21 \mathrm{~kg})$ were used to evaluate nutrients digestibility and $\mathrm{N}$ utilization of $\mathrm{AH}, \mathrm{AS}, \mathrm{AH}+\mathrm{PEG}$ and berseem (Trifolium alexandrinum) hay $(\mathrm{BH})$ rations. The $\mathrm{BH}$ was used as a control ration. Crushed barley grains were offered to cover $50 \%$ of maintenance requirements for sheep (ARC, 1965) and goats (NRC, 1981), while tested forages were offered ad lib. Drinking fresh water was available for the experimental animals.

Proximate analysis and $\mathrm{Na}$ were determined according to A.O.A.C., (1990) methods. Goering and Van Soest, (1970) methods were used to determine cell wall constituents (CWC). Tannin was determined according to Pharmacopoeia Europian, 
(1974, 1975 and 1978). Data obtained in this study was statistically analyzed according to SAS (1990). Differences among means were examined using Multiple Range Test according to Duncan, (1955).

\section{RESULTS}

The data presented in Table (1) showed that nutrients proximate analyses of $A$. halimus were comparable to those of berseem hay. However, it showed better $\mathrm{CP}$ content $13.45 \%$ vs $11.84 \%$. Atriplex halimus showed the highest ash $(20.05 \%)$ and $\mathrm{Na}(3.96 \%)$ contents. Calculated $\mathrm{NaCl}$ (Ishihawa et al., 2002) content of $A$. halimus would be $10.50 \%$. It contained $95.6 \mathrm{~g} / \mathrm{kg}$ total tannin.

Table 1. Chemical analysis of experimental rations ingredients

\begin{tabular}{lllll}
\hline Item & $\mathrm{BH}$ & $\mathrm{AH}$ & $\mathrm{AS}$ & $\mathrm{BG}$ \\
\hline $\begin{array}{l}\text { Moisture, \% } \\
\text { Proximate analysis ( DM basis), \% }\end{array}$ & 12.51 & 12.30 & 65.53 & 10.20 \\
OM & 88.66 & 79.95 & 79.65 & 93.28 \\
CP & 11.84 & 13.45 & 13.99 & 8.49 \\
CF & 24.97 & 30.19 & 26.34 & 9.59 \\
EE & 3.09 & 4.80 & 4.17 & 1.54 \\
NFE & 60.10 & 31.51 & 35.15 & 73.66 \\
Ash & 11.34 & 20.05 & 20.35 & 6.72 \\
Cell wall constituents ( DM basis), \% & & & & \\
NDF & 35.43 & 48.34 & 48.27 & 28.67 \\
ADF & 19.05 & 32.57 & 33.04 & 15.79 \\
ADL & 8.44 & 11.85 & 11.42 & 2.17 \\
\hline
\end{tabular}

$\mathrm{BH}=$ Berseem hay; $\mathrm{AH}=$ Atriplex hay; $\mathrm{AS}=$ Atriplex silage; $\mathrm{BG}=$ Barley grains.

The daily DM intake (Table 2) by both sheep and goats from barley to cover $50 \%$ of their maintenance requirement was $19.44 \mathrm{~g} / \mathrm{kg} \mathrm{w}^{0.75}$. The dry matter intake (DMI) from the experimental forages as shown in Table (2) was variable. Both animal species consumed higher average amounts from $\mathrm{BH}\left(32.56 \mathrm{~g} / \mathrm{kg} \mathrm{w}^{0.75}\right)$ than $\mathrm{AH}$, AS

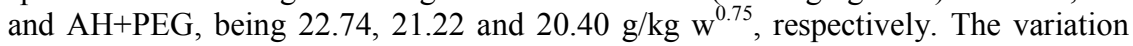
within DM of the latter three rations was in narrow limits. Differences between sheep and goats were out of the study objectives, therefore the results mean values for the two species were used.

The $\mathrm{BH}$ ration showed better nutrients digestibilities than the other three rations A. halimus (Table 2). The differences were significant $(\mathrm{P}<0.01)$ between those of $\mathrm{BH}$ and $\mathrm{AH}$ and $\mathrm{AH}+\mathrm{PEG}$ ( except for $\mathrm{CP}$ ), where there were no significant differences compared with those of AH+PEG. Accordingly, these results were reflected on better $(\mathrm{P}<0.01)$ TDN and DCP values. Ensiling A. halimus showed better $(\mathrm{P}<0.01)$ digestibilities for all nutrients than feeding it as hay alone or with $\mathrm{PEG}$, except $\mathrm{CP}$ digestibility of $\mathrm{AH}+\mathrm{PEG}$ which showed comparable values. Supplementing animals fed $\mathrm{AH}$ by $\mathrm{PEG}$ improved $(\mathrm{P}<0.01) \mathrm{CP}$ digestibility, being $49.31 \%$ for $\mathrm{AH}$ vs $54.19 \%$ for $\mathrm{AH}+\mathrm{PEG}$, however it was almost similar to AS (54.22\%). 


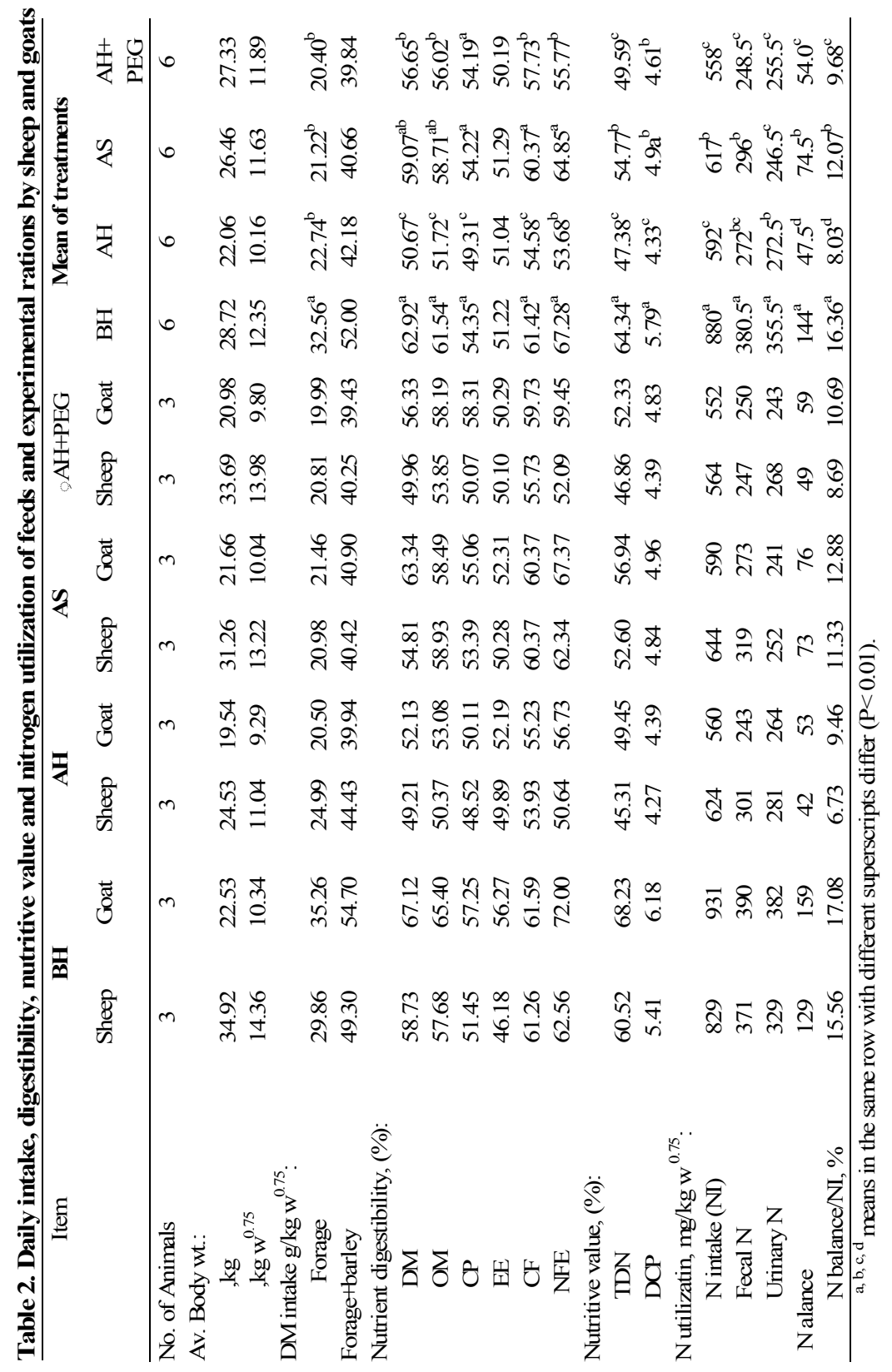


The data (Table 2) of daily $\mathrm{N}$ balance of $\mathrm{BH}$ ration showed the highest $(\mathrm{P}<0.01) \mathrm{N}$ balance which was reflected on high $\mathrm{N}$ balance / $\mathrm{N}$ intake percent than rations contained $A$. halimus.

Ensiling A. halimus showed better $(\mathrm{P}<0.01) \mathrm{N}$ balance and accordingly $\mathrm{N}$ balance / $\mathrm{N}$ intake percent than being fed as $\mathrm{AH}$ or $\mathrm{AH}+\mathrm{PEG}$.

Supplementing animals by $\mathrm{PEG}$ showed better $(\mathrm{P}<0.01)$ nitrogen retention than animals fed $\mathrm{AH}$ rations. Meanwhile, $\mathrm{PEG}$ supplementation improved $(\mathrm{P}<0.01) \mathrm{N}$ retained / $\mathrm{N}$ intake percent, being $8.03 \%$ for $\mathrm{AH}$ and $9.68 \%$ for $\mathrm{AH}+\mathrm{PEG}$ rations.

\section{DISCUSSION AND CONCLUSION}

Both berseem hay and Atriplex halimus showed comparable chemical nutrients contents. Nevertheless, dry matter intake by both sheep and goats from $\mathrm{BH}$ was higher $(\mathrm{P}<0.01)$ than $\mathrm{AH}$. In the other words, $\mathrm{AH}$ was less palatable than $\mathrm{BH}$. This result might be due to high ash, $\mathrm{Na}$ and $\mathrm{NaCl}$ contents. Moreover, $\mathrm{AH}$ contained considerable amounts of total tannin, being $95.6 \mathrm{~g} / \mathrm{kg} \mathrm{DM}$, which seems to be an antinutritional factor which decreased its palatability. Getachew et al., (2002) found that total tannin content in browsed plant species were from 7 to $214 \mathrm{~g} / \mathrm{kg} \mathrm{DM}$.

Supplementing both sheep and goats by PEG as a tannin complexing agent did not obviously affect AH palatability measured as DM intake. This result agreed with Decandia et al. (2000) who reported that PEG supplementation did not affect DM intake. Nevertheless, it caused higher $(\mathrm{P}<0.01)$ increase in organic matter digestibility and crude protein digestion and utilization. They found that the in vivo $\mathrm{CP}$ digestibility of the diet increased from $37 \%$ without PEG to $71 \%$ with $50 \mathrm{~g}$ PEG supplementation. Moreover, Silanikove et al., (1996) reported a significant increase in organic matter digestibility of Mediterranean browses from maintenance level to levels considerably exceeding the maintenance requirements of goats as a result of daily supplementation of PEG. The present results were in line with the above authers findings showing that 20g PEG daily supplementatin enhanced $(\mathrm{P}<0.01)$ organic matter and crude protein digestibilities of $\mathrm{AH}$ by sheep and goats. Moreover, PEG improved $(\mathrm{P}<0.01) \mathrm{CP}$ utilization estimated as $\mathrm{N}$ balance and $\mathrm{N}$ balance / $\mathrm{N}$ intake percent. Similar trends were obtained by Decandia et al. (2000) who found that PEG increased the intake of digestible $\mathrm{N}$ and tended to increase $\mathrm{N}$ balance.

Ensiling $A$. halimus as a process to ameliorate the anti- nutritional factors effect on both sheep and goats showed better $(\mathrm{P}<0.01)$ nutrients digestibiliy and nutritive value as energy (TDN) or digesible crude protien (DCP) than untreated one, however, it did not affect its palatability measured as dry matter intake. Atriplex silage showed better $(\mathrm{P}<0.01) \mathrm{N}$ balance and $\mathrm{N}$ balance / $\mathrm{N}$ intake percent than rations contained $A$. halimus with or without $\mathrm{PEG}$.

Ensiling A. halimus as a browse forage showed comparable results to PEG supplementation. In the mean time this process might be easier and might lower feeding cost than daily PEG supplementation. Therefore, it might be preferable than the later one in developing countries to ameliorate the anti-nutritinal factors effect of browsed plant species on ruminant livestock. 


\section{REFERENCES}

A.O.A.C., 1990. Association of Official Analytical Chemists: Official Methods of Analysis $\left(15^{\text {th }} \mathrm{Ed}\right)$ Washington, D.C., U.S.A.

ARC, 1965. The Nutrient Requirements of Farm Livestock. Ruminants. Agriculture Research Council, London.

Decandia, M., M. Sitzia, A. Cabiddu, D. Kababya and G. Molle, 2000. The use of polyethene glycol to reduce the anti- nutritional effects of tannins in goats fed woody species. Small Ruminant Research, 38: 157- 164.

Duncan, D.B., 1955. Multiple range and multiple F-test. Biometrics, 11.1.

Fagg, C.W. and J.L. Stewart, 1994. The value of Acacia and Prosopis in arid and semi-arid environments. J. Arid Environments, 27: 3-25.

Getachew, G., H.P.S. Makkar and K. Becker, 2002. Tropical browses: contents of phenolic compounds, in vitro gas production and stoichiometric relationship between short chain fatty acid and in vitro gas production. J. Agric. Sci. Camb., 139: 341-352.

Gihad, E.A., 1993. Utilization of high salinity tolerant plants and saline water by desert animals. H. Lieth and A. Al Masoom (eds) : Towards the rational use of high salinity tolerant plants, Vol, 1: 443- 447.

Goering, H.K. and P.J. Van Soest, 1970. Forage Fiber Analysis U.S.D.A. Agric. Handbook No. 379. Washington, DC, pp. 89.

Ishikawa, N., K. Shimizu, T. Koizumi, T. Shimizu and O. Enish, 2002. Nutrients value of Saltwort (Salicornia herbacea L.) as feed for ruminants. Asian-Aust. J. Anim. Sci., 15: 98.

Jones, W. T., L.B. Anderson and M.D. Ross, 1973. Bloat in cattle: detection of protein precipitants (flavolans) in legumes. New zealand J. Agric. Res., 16: 441446.

Le Houerou, H.N., 1993. Environmental aspects of fodder trees and shrubs plantation in the Mediterranean Basin. In: V. Papanastasis (Editor). Agriculture Agrimed Research Program : Fodder trees and shrubs in the Mediterranean production systems: Objectives and expected results of the EC research contract. C.E.C., pp.11-34.

McSweeney, C.S., B. Palmer, D.M. Mcneil and D.O. Krause, 2001. Microbial interactions with tannins: nutritional consequences for ruminants. J. Anim. Feed Sci. Tech., 91: 83- 93.

NRC, 1981. Nutrition Requirements of Goats. National Academy of Science, Washington. D.C.

Pharmacopoeia Europian, 1974, 1975 and 1978. Deutscher, Apotheker Verlag, Stutle gart, Gavi Verlag Gmbh Frankfort / M.

SAS, 1990. SAS Institute, Inc., SAS/STST Guide for Personal Computers.

Silanikove, N., A. Giboa, I. Nir, A. Perevolotsky and Z. Nitsan, 1996. Effect of a daily supplementation of polyethelene glycol on in intake and digestion of tannincontaining leaves (Quercus calliprinos, Pistacia lentiscus and Ceratonia siliqua) by goats. J. Agric. Food Chem. 44: 199- 205. 
Silanikove, N., N. Giloboa and Z. Nitsan, 1997. Interaction among tannin supplementation and polyethelene glycol in goats fed Oak leaves. J.Anim. Sci., 64: 479- 483

Terrill, T.H., G. B. Douglas, A.G. Foote, R. W. Purchas, G.F. Wilson and T.N. Barry, 1992. Effect of condensed tannins upon body growth, wool growth and rumen metabolism in sheep grazing Sulla (Hedysarum coronarlum) and perenial pasture. J. Agric. Sci. Camb., 119: 265-273.

Waghorn, G.C. and I.D. Shelton, 1997. Effect of condensed tannins in Lotus corniculatus on the nutritive value of pasture for sheep. J. Agric. Sci. Camb., 128: 365-372.

Waghorn, G.C., I.D. Shelton, W.C. Mcnabb and S.N. Mccutcheon, 1994. Effect of condensed tannins in Lotus pedunculatus on its nutritive value for sheep. 2. Nitrogen aspects. J. Agric. Sci. Camb., 123: 109-119. 
الحد من أثر المواد الضارة فى نبات القطف الملحى على الأغنام والماعز بواسطة السيلجة أو إضافة مادة البولى ايثلين جليكول

\section{هاشم حامد عبد الرحمن، ممدوح إبراهيم محمد، أحمد السيد أحمد جهاد، إبراهيم محمد عوض الله.}

$$
\text { قسم الإنتاج الحيوانس، المركز القومى للبحوث، الدقى، الجيزة }
$$

تم الحش والحصول على كميات من الأغصان والفروع الغضة من نبات القطف الملحى والموجودة بصورة

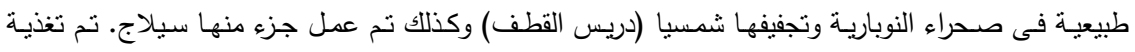

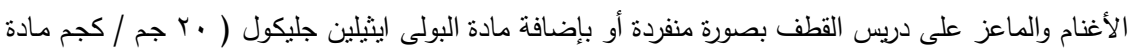

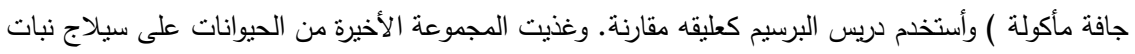

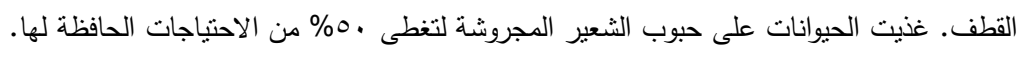

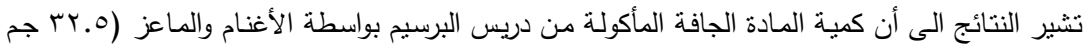

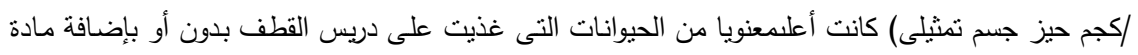

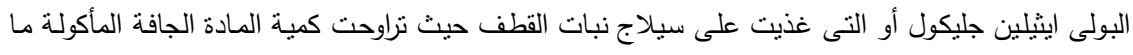

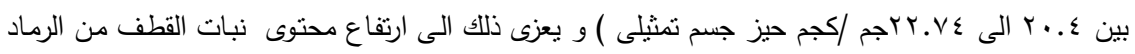
وكلوريد الصوديوم والتانينات.

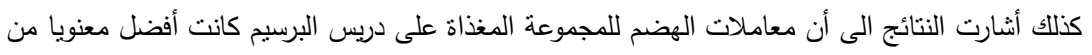

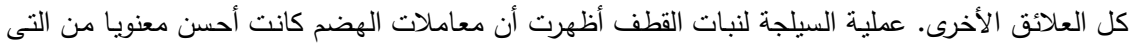

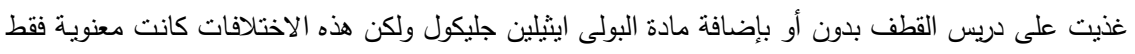

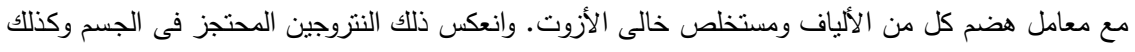

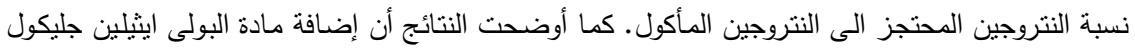

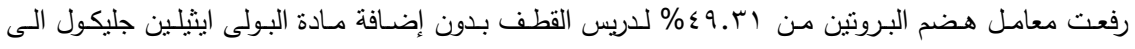

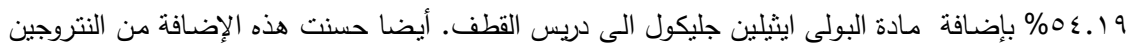

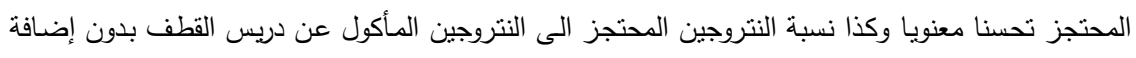

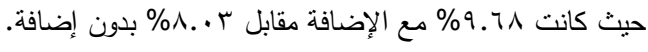

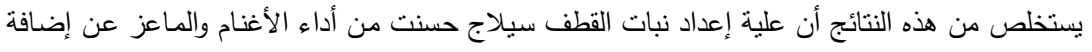
مادة البولى ايثيلين جليكول الى دريس القطف كما أنها أسهل من الناحية العملية وذات نكلفة أقلى 